\title{
DEVELOPING ENGLISH READING MATERIALS FOR THE ELEVENTH GRADE STUDENTS OF SOFTWARE ENGINEERING PROGRAM AT SMKN 9 MEDAN
}

\author{
*Chicy Ramadhayanty \\ **Rafika Dewi Nasution, S.Pd., M.Hum
}

\begin{abstract}
Chicy Ramadhayanty, 2161121005. Developing English Reading Materials for The Eleventh Grade Students of Software Engineering Program at SMKN 9 Medan. A Thesis, English Educational Program, Faculty Language and Arts, State University of Medan, 2021.
\end{abstract}

The objective of this study was to develop English reading materials based on the students of Software Engineering needs for the eleventh grade students at SMKN 9 Medan. This study was conducted by using Research and Development design through six stages; gathering data and information, need analysis, designing materials, validating, revising (final product). The subject of the study was grade eleventh of SMKN 9 Medan. The data were gathered by conducting interview to English teacher and distributing questionnaire to XI RPL 3 consists of 24 students to get the students' need. To collect the data of the research, conducting interview to English teacher and two types of questionnaires were used as the instruments. The developed reading materials were validated by two experts which are the average scores for the analytical exposition material (4.65 and 4.7) and for the explanation text (4.65 and 4.6) show that the reading materials are valid and suitable to use for the eleventh grade students of software engineering program. Based on the results of the expert judgment, the developed materials were considered appropriate, which was very good.

Key words: Development, Reading Materials, Software Engineering.

\footnotetext{
*Graduate Status

**Lecturer Status
} 


\section{INTRODUCTION}

In the world of education in Indonesia, there are two categories, namely the senior high school (SHS) and the vocational high school (VHS). SHS focuses on knowledge expansion and skills improvement of students and prepares students for further higher education while VHS focuses on the development of specific skills that apply to certain specific occupation. Vocational School has different goal from Senior High School. Risangkusmo, W (2015) states the main difference between the vocational high school and the high school in general is the preparation for the students to get particular jobs soon after they graduate. Generally, SHS does not provide certain majors like vocational school and it does not prepare the students ready to work. Meanwhile, the students in vocational school should learn English based on their specific needs by the students' course.

The fact shows a contrast with the concepts of English for Specific Purpose (ESP). Hutchinson and Waters (1987:53) accentuate that what distinguishes ESP from General English is the awareness for the former towards the students' needs. The learning materials has been developed so as to be the guidance for the English teacher, in order to consider the learning needs. Based on interview, the English teacher stated that the government only provides the similar textbook with the same content every year. The teacher should find other resources to teach them.

Software Engineering is one of departments provided in SMKN 9 Medan. To support the preliminary data taken by the interview, on observation has also been conducted in the BAHASA INGGRIS book published by Kementerian Pendidikan dan Kebudayaan Republik Indonesia 2017. It was found the materials 
in the book are not related to software engineering major. Ideally, the topics of the materials for learning English should be closely related to software engineering, the students need English materials containing input texts that are related to their study program.

However, the English learning materials for every department at SMKN 9 Medan are not ideal yet. The reading part does not contain relevant input texts and technical terms that are needed by the students in software engineering. Therefore, the teachers at SMKN 9 Medan created their own learning materials by adapting some learning materials from various resources. This is just a temporary solution and they are still waiting for the learning materials intended for the vocational high school. So, from the original or the general book, the teacher should develop materials based on the learning objectives. Based on this problem, there is a need to develop learning materials that is suitable for the students there, especially in reading texts.

\section{REVIEW OF LITERATURE}

\section{A. Theoretical of framework}

In supporting the idea of this study, the research presented some books containing information and theories that helped the researcher to design this thesis proposal. Theories are very important because they are used as the basic foundation in conducting the analysis of this research.

\section{Reading Theories}

\section{a. The Nature of Reading}

Reading is important skill for students, because the students must able to read and understand an English text. Reading can be used by the English teacher as a media to teach other language skills such as listening, speaking, and writing 
and also language elements such as vocabulary, pronunciation, and grammar. Reading is fluent process of readers combining information from a text and their own background knowledge to build meaning (Nunan, 2003:68). Reading is not just read the text but the readers must have known the knowledge so that the readers will be able to get the meaning of what the text tells about.

According to Klingner, Vaughn and Boardman (2007) reading is process construsting meaning that can be achieved through dynamic instruction suggested by the text, and the context of the reading situation. It is also supported by Mc. Entire (2003) who defines reading as a constructive process which the prior knowledge and experience affects the reader's comprehension of the text. Appropriate comprehension is possible to obtain as the content of the text is close to the reader's prior knowledge, such as a doctor who reads a medical article would find it better in comprehending the text than the farmer.

\section{The Teaching of Reading}

\section{a. Teaching Reading in Grade XI Vocational High School}

As mentioned in the Act of National Education System No. 20/2003, a curriculum is a set of plans which are used as the guideline in the teaching and learning process to achieve some specific purposes of education. Since the 2013/2014 academic year, Curriculum 2013 is applied in Indonesia. Not all schools, including vocational high schools, have implemented it yet. Some of them have changed the curriculum while the others still use School-based Curriculum (KTSP).

In Curriculum 2013 for vocational high schools, English core competences are formulated in four aspects in which each aspect is explained further in basic 
competences. The following table shows the example of reading competence for Grade XI according to the Act of Ministry of Education and Culture No. 22/2016.

\section{a. Reading Material for Vocational High School}

In our daily life, people read for two basic reasons: for pleasure and for information (Grellet, 1981). In the vocational high school, in this case, it deals with the second reason of doing reading, it is to get information. In line with that, the information for the reading materials should be gathered from sources

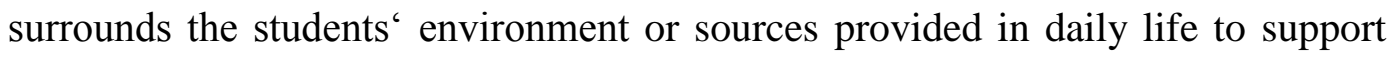
students in achieving basic competency or goals of the subject.

Referring to teaching English in vocational high schools, it is closely related to the approach of English for Specific Purposes (ESP) since the students are prepared to be ready to cope with their specific fields. Therefore, if the criteria above have been fulfilled, reading materials should also provide exposure to the specialized genres and registers of ESP (Richards, 2001)

On the contrary, the English course book provided especially for Grade XI students of vocational high schools does not completely fulfill the criteria for good reading materials. The book published by Ministry of Education and Culture for Curriculum 2013 only covers general English and it is used for both senior high schools and vocational high schools as well. Thus, this research is aimed to develop the appropriate materials for Grade XI students of vocational high schools especially for the Software Engineering Program. The materials will be based on the core and basic competences for Grade XI of vocational high schools in Curriculum 2013. 


\section{Types of Texts}

\section{a. Analytical Exposition}

Martine and Rose (2003:11) define exposition text is one of persuasive texts and there are two types of exposition text, those are analytical exposition and hortatory exposition. Analytical exposition text is an exposition text that function is to justify position and persuade the reader or listener something in the case. Gerot and Wignell (1994:197) state the purpose of analutical exposition is to persuade the readers that something in the case.

\section{b. Explanation text}

Explanations are written to explain how something works or occurs. The process of the events is explained sequentially and with the time related information (Law, 2013, p.17).

"Explanation genre requires students to demonstrate knowledge and understanding, and to answer questions, such as "What is $\mathrm{x}$ ?"e, and additionally expect students to explain how something works or function. The explanations themselves are intended to demonstrate current shared knowledge and understanding (Nesi \& Gardner, 2012, p.36).”

The researcher concludes that explanation text is a text used to explain the process of a phenomenon, events or action. It is also used to share the fact of knowledge and understanding.

\section{English For Spesific Purpose}

\section{a. Definition of ESP}

Hutchinson and Waters $(1987: 19)$ state that "ESP is an approach to language teaching in which all decisions as to content and method are based on 
the learner's reason for learning". ESP has characteristics in which the teaching and learning concern on how students can meet the specific needs they want to learn (Anthony, 1997:1). This is in line with Graves (2000) who proposes that ESP is illustrated as an umbrella of teaching and learning process for specific purpose. Basturkmen (2006:17) also supports the idea in which ESP is about preparing learners to use English within academic, professional, or workplace environment. In language teaching, ESP is important as Nunan (2004:7) in Basturkmen (2006:17) also declares that ESP is the subcomponet of language teaching, with its own approaches to curriculum development, materials design, pedagogy, testing and research.

\section{b. Need Analysis}

To identify what the needs of the ESP learners, Hutchinson \& Waters (1987:55) devide two terms called target needs and learning needs. Target needs include neccesities, lacks, and wants, while learning needs cover what the learners need to do. The first analysis should be done is target needs which are described as something will be needed by the learners in the future, especially the use of language (Hutchinson \& Waters: 1987). They divide the target needs into three aspects: necessities, lacks, and wants.

\section{Software Engineering}

Software Engineering Program in vocational school has a purpose to train and to prepare the students to be a proffesional software engineering so the students will be able to use their ability in developing operating systems, web-based applications and so on, when they will get to work. Many people think that software is simply another word for computer programs. However, 
when we are talking about software engineering, software is not just the programs themselves but also all associated documentation and configuration data that is required to make these programs operate correctly. Ian Sommerville in his book Software Engineering (2011) explain that software engineering is an engineering discipline that is concerned with all aspects of software production that deal with software specification, software development, software validation, and software evolution.

\section{Materials Development}

According to Tomlinson (1998:2) materials development refers to any process which is done by writers, teachers, or learners to produce sources or input as the intake to expose the language use in teaching and learning process. Further, Tomlinson mentions some examples of the sources or input that can be categorized as materials development, such as developing textbooks, telling stories, bringing advertisement into classroom, providing samples of language use, or reading a poem aloud. He also explains that materials development concentrates on two vital things, that is, what should be given to the learners and what can be done with it to promote language learning.

In line with Tomlinson, material development is basically dealing with selection, adaptation, and creation of teaching materials (Nunan, 1991). In short, materials development is needed since the available materials should be renewed or replaced depending on the progress or demand related to the subject matter. The materials developer then should develop materials and follow some steps to design materials that suit to the needs of the learner. The 
following part will explain about the certain model that can be used to develop materials.

\section{RESEARCH METHODOLOGY}

This research conducted by using developmental research. The research and development (R\&D) design raised by Borg and Gall aim to develop and validate products of education such as curriculum, syllabus, lesson plan, textbooks, media, modules, assessment, instrument, etc. The research findings were used to develop new products and procedures. This research was conducted in SMAKN 9 MEDAN which is located in Jln. Patriot No.20A, Lalang, Kec. Medan Sunggal, Kota Medan. The subject of the research was the eleventh grade students XI RPL 3 consists of 24 students of Software Engineering Program at SMK N 9 Medan.

In collecting the data, this research was conducted by observing and reviewing the documents such as syllabus and textbook. Then interviewing teacher in order to find information about the reading materials that teacher used in classroom and the problem that teacher faced while using it and distributing questionnaires to students in order to find out the students' needs to obtain the data about the developing of reading materials.

After gathering data, infromation and need analysis, researcher desgined the reading materials, then validated to experts, revised, and the result of revised product was the final product, these steps were adopted from Borg and Gall's research and development theory (2003:596), with some modifications which become 6 steps of $\mathrm{R} \& \mathrm{D}$ cycle. 


\section{RESEARCH FINDINGS AND DISCUSSION}

\section{A. Research Findings}

The developing reading materials were developed by using several stages, those are:

1). Gathering data. The data were gathered by using questionnaire, reviewing document and interviewing. The questionnaire was showed that the students were wanted the reading materials which could be motivated them to learn English. Based on the reviewing documents (syllabus, textbook), the basic competence in syllabus stated that the eleventh grade students had to be able to capturing contextual meanings related to social functions, text structures, and linguistic elements of analytical exposition and explanation text, the syllabus. Then researcher found that the teacher used reading materials only from textbook and in the textbook there were 2 sections each of reading. After reviewing the textbook, researcher found that the existing reading materials were not suitable with vocational high school, the reading materials in the textbook still did not provide based on their specific needs.

After reviewing the documents, researcher also got information from interviewing teacher, based on interview teacher said that teaching reading usually done after 2 times meeting, it depends on the class. The interview was showed in teaching reading teacher faced that the materials in the textbook were not interesting for students, students were bored and students were not interested with the reading text in textbook. Teacher also said that the reading materials in the textbook were not enough to fulfill students' needs. 
2). Need Analysis. The questions related to the students' necessities were asked in order to know what they should achieve so that they can fulfill the demands of the target situation. For this aspect, there were three questions which were given and the results are shown in the following table.

Table 4.1 The Students' Necessities

\begin{tabular}{|c|c|c|c|c|}
\hline Aspects & Statements & $\mathbf{N}$ & $\mathbf{F}$ & Percentage \\
\hline Necessities & \multicolumn{4}{|c|}{$\begin{array}{l}\text { After graduating from vocational high school, the students use } \\
\text { English in their field to... }\end{array}$} \\
\hline & $\begin{array}{l}\text { a. communicate actively in written } \\
\text { or oral }\end{array}$ & 24 & 10 & $41,7 \%$ \\
\hline & $\begin{array}{l}\text { b. read any written texts related to } \\
\text { software engineering }\end{array}$ & 24 & 1 & $4,1 \%$ \\
\hline & $\begin{array}{l}\text { c. understand English technical } \\
\text { terms in the field of software } \\
\text { engineering }\end{array}$ & 24 & 13 & $54,2 \%$ \\
\hline Necessities & \multicolumn{4}{|c|}{$\begin{array}{l}\text { According to the students, the use of texts related to software } \\
\text { engineering in the teaching and learning process of reading is... }\end{array}$} \\
\hline & a. very important & 24 & 18 & $75 \%$ \\
\hline & b. important & 24 & 6 & $25 \%$ \\
\hline & c. less important & 24 & 0 & 0 \\
\hline & d. not important & 24 & 0 & 0 \\
\hline Necessities & \multicolumn{4}{|c|}{$\begin{array}{l}\text { Types of English texts that the students will often face in their } \\
\text { future job are... }\end{array}$} \\
\hline & a. descriptive text & 24 & 4 & $16,7 \%$ \\
\hline & b. report text & 24 & 3 & $12,5 \%$ \\
\hline & c. procedure text & 24 & 12 & $50 \%$ \\
\hline & d. explanation text & 24 & 2 & $8,3 \%$ \\
\hline & e. analytical exposition & 24 & 3 & $12,5 \%$ \\
\hline
\end{tabular}

From the first item, many students stated that in the working fields, they need to understand English technical terms in the field of software engineering. The percentage is $54,2 \%$. In the developed reading learning materials, some texts and tasks are provided to facilitate the students in understanding some certain technical terms. Since the product of this research is English learning materials which focus on the reading skill, it may help the students to partly fulfill this kind 
of necessities. Nevertheless, after graduating from vocational high schools, 41,7\% of the students stated that they would use English in the working fields to communicate actively in written or oral form.

The second item was provided in order to know the students' opinion about how important the use of texts which are related to their study program in the teaching and learning process of reading is. As what is shown in Table 4.2, $75 \%$ of the students believed that it was very important.

Lacks refer to the gap between the students' current knowledge and the required level in the target situation. In this case, the students were asked about their current level of English proficiency and reading ability. The results are presented in the following table.

Table 4.2 The Students' Lacks

\begin{tabular}{|c|c|c|c|c|}
\hline Aspects & Statements & $\mathbf{N}$ & $\mathbf{F}$ & Percentage \\
\hline Lacks & \multicolumn{4}{|c|}{ My current level of English proficiency is... } \\
\hline & a. Beginner & 24 & 14 & $58,3 \%$ \\
\hline & b. Intermediate & 24 & 10 & $41,7 \%$ \\
\hline & c. Advanced & 24 & 0 & 0 \\
\hline Lacks & \multicolumn{4}{|c|}{ The current students' reading ability is... } \\
\hline & a. very good & 24 & 1 & $4,2 \%$ \\
\hline & b. good & 24 & 8 & $33,3 \%$ \\
\hline & c. average & 24 & 12 & $50 \%$ \\
\hline & d. low & 24 & 3 & $12,5 \%$ \\
\hline
\end{tabular}

According to Table 4.3, the first item shows that the number of the students who were in the beginner level of English proficiency. The percentage is $50 \%$. 
For the more specific aspect which is the current students' reading ability, the results are different. As can be seen in Table $4.3,50 \%$ of the students considered that they were in the average level.

Wants can be defined as what the students wish to be included in the materials. There are two items that are related to this aspect. The results of the students' wants are shown in the table below.

Table 4.3 The Students' Wants

\begin{tabular}{|c|c|c|c|c|}
\hline Aspects & Statements & $\mathbf{N}$ & $\mathbf{F}$ & Percentage \\
\hline Wants & \multicolumn{4}{|c|}{$\begin{array}{l}\text { The kinds of input that the students want in the teaching and } \\
\text { learning process of reading are... }\end{array}$} \\
\hline & a. articles, magazine and newspaper & 24 & 4 & $16,7 \%$ \\
\hline & $\begin{array}{l}\text { b. brochures, advertisements, and } \\
\text { labels }\end{array}$ & 24 & 1 & $4,2 \%$ \\
\hline & $\begin{array}{l}\text { c. texts which are related to } \\
\text { software engineering }\end{array}$ & 24 & 17 & $70,8 \%$ \\
\hline & d. academic texts & 24 & 2 & $8,3 \%$ \\
\hline Wants & \multicolumn{4}{|c|}{$\begin{array}{l}\text { In relation to the students' needs, the kinds of reading skills that } \\
\text { they want to improve are ... }\end{array}$} \\
\hline & a. vocabulary & 24 & 10 & $41,7 \%$ \\
\hline & b. grammar & 24 & 6 & $25 \%$ \\
\hline & c. comprehending the texts & 24 & 3 & $12,5 \%$ \\
\hline & d. reading effectively & 24 & 5 & $20,8 \%$ \\
\hline
\end{tabular}

From the table above, in the first item, $70,8 \%$ of the students stated that the kinds of input that they wanted were texts which are related to software engineering. It becomes one of the considerations in developing the reading learning materials.

3) Designing Materials. After administering the needs analysis, the appropriate analytical exposition and explanation text materials for reading skill students of XI grade students at SMKN 9 Medan were identified. The main point was 
analytical and explanation text materials should consist of the appropriate materials for their major. So that, the researcher developed reading materials based on basic competences and also in designing analytical and explanation text reading materials based on scientific approach. The researcher developed indicator into the lesson plan, and then the materials developed related to the stages of scientific approach.

4) Validating by the experts,

The first expert was Prof. Dr. Sumarsih, M.Pd, the result was described as follow:

Table 4.4 Validation data by the first expert (Analytical Exposition text)

\begin{tabular}{|c|c|c|c|c|}
\hline No. & Criteria & $\begin{array}{c}\text { The Number } \\
\text { of Criteria }\end{array}$ & $\begin{array}{l}\text { Maximum } \\
\text { of Criteria }\end{array}$ & Score \\
\hline 1 & Product and Content & 7 & 35 & 32 \\
\hline 2 & Linguistic & 5 & 25 & 24 \\
\hline 3 & Process / Setting & 5 & 25 & 23 \\
\hline 4 & Layout & 3 & 15 & 14 \\
\hline & Total & 20 & 100 & 93 \\
\hline
\end{tabular}

Table 4.5 Validation data by the first expert (Explanation text)

\begin{tabular}{|c|c|c|c|c|}
\hline No. & Criteria & $\begin{array}{c}\text { The Number } \\
\text { of Criteria }\end{array}$ & $\begin{array}{l}\text { Maximum } \\
\text { of Criteria }\end{array}$ & Score \\
\hline 1 & Product and Content & 7 & 35 & 32 \\
\hline 2 & Linguistic & 5 & 25 & 24 \\
\hline 3 & Process / Setting & 5 & 25 & 23 \\
\hline 4 & Layout & 3 & 15 & 14 \\
\hline & Total & 20 & 100 & 93 \\
\hline
\end{tabular}


The average score of validation from the first validator was 4.65 or $93 \%$ for reading materials of analytical exposition and explanation text, based on categorized above it was relevant or very good. Thus, the final draft of developed reading materials were valid and suitable to be used as learning materials for eleventh grade students for software engineering program.

The second expert was Julita Bakara, S.Pd, an English teacher in SMKN 9 Medan.

Table 4.6 Validation data by the second expert (Analytical Exposition text)

\begin{tabular}{|c|c|c|c|c|}
\hline No. & Criteria & $\begin{array}{c}\text { The Number } \\
\text { of Criteria }\end{array}$ & $\begin{array}{l}\text { Maximum } \\
\text { of Criteria }\end{array}$ & Score \\
\hline 1 & Product and Content & 7 & 35 & 32 \\
\hline 2 & Linguistic & 5 & 25 & 24 \\
\hline 3 & Process / Setting & 5 & 25 & 24 \\
\hline 4 & Layout & 3 & 15 & 14 \\
\hline & Total & 20 & 100 & 94 \\
\hline \multicolumn{5}{|c|}{ Average: $94 / 20=4.7$ or percentage $94 / 100=94 \%$} \\
\hline
\end{tabular}

Table 4.7 Validation data by the secind expert (Explanation text)

\begin{tabular}{|c|c|c|c|c|}
\hline No. & Criteria & $\begin{array}{c}\text { The Number } \\
\text { of Criteria }\end{array}$ & $\begin{array}{l}\text { Maximum } \\
\text { of Criteria }\end{array}$ & Score \\
\hline 1 & Product and Content & 7 & 35 & 32 \\
\hline 2 & Linguistic & 5 & 25 & 23 \\
\hline 3 & Process / Setting & 5 & 25 & 23 \\
\hline 4 & Layout & 3 & 15 & 14 \\
\hline & Total & 20 & 100 & 92 \\
\hline \multicolumn{5}{|c|}{ Average: $92 / 20=4.6$ or percentage $92 / 100=92 \%$} \\
\hline
\end{tabular}

The average score of validation from the second validator was 4.7 or $94 \%$ for reading material of analytical exposition and then for the explanation text the validator gave the score was 4.6 or $92 \%$, based on categorized above it was 
relevant and also very good. It means that the materials were valid and suitable to use for eleventh grade students of SMKN 9 Medan.

5) Revision, after giving the materials to the experts/validators, there were some revisions suggested by them. Validators suggested the instruction should explain clearly how to do the task, make the layout and the design be more interesting and provide more kinds of reading exercises, and to provide more vocabulary list and also about the layout should add the picture that interest the students, the teacher said that the placement of titles, subtitles, text in each unit were consistent.

6) Final Product. The final product was developed based on the suggestions and the comments of the first draft of the reading materials from the expert.

\section{B. Discussion}

The purpose of the study is to find out the students' needs and develop the English reading materials for the eleventh grade students at SMKN 9 Medan. As what has been planned, the researcher used the R \& D method by Borg and Gall (2003). The materials developed by the researcher related to syllabus based on their needs. The materials were developed according to the concept of English for Specific Purposes (ESP) suggested by Hutchinson and Waters (1991). In designing reading materials, the researcher developed materials based on scientific approach stages, so that researcher developed indicators into the lesson plan, and then the materials developed related to the stages, such as in the observing, questioning, experimenting, associating and communicating. 
In designing the text, researcher designed the text based revewing the textbook. The book published by Ministry of Education and Culture for Curriculum 2013 only covers general English and it is used for both senior high schools and vocational high schools. The materials developed based on the core and basic competences for Grade XI of vocational high schools in Curriculum 2013. After the first draft of the materials being evaluated, the final step of this research procedure was revising the developed materials based on the feedback and suggestions from the experts. The revised materials were then considered as the final draft of the materials.

\section{CONCLUSION AND SUGGESTIONS}

\section{A. Conclusion}

Generally, the existing reading materials are not suitable with vocational high school level. The developed reading materials were designed for 2 times meetings, and every meeting used stages of scientific approach (observing, questioning, exploring, associating, and communicating). And then, when the developed the materials, the researcher distributed the questionnaires. In terms of the target needs and learning needs. In target needs, there are four aspects to be observed. They are goals, necessities, lacks, and wants.

The developed reading materials were validated by two experts which are the average scores for analytical exposition are $(4,65$ and 4,7$)$ and for the explanation text are $(4,65$ and 4,6$)$ show that the reading materials are valid and suitable to use for the eleventh grade student of software engineering program. After the developed reading materials were validated by the experts, the reading materials can be used. 


\section{B. Suggestion}

1. For XI grade Students of the software engineering program

In order to improve their English skills especially in reading, XI grade Students of the software engineering program who are going to use the developed materials are suggested to actively participate in the teaching and learning process and do the tasks accordingly.

2. For the English teachers of the software engineering program To achieve the goal of teaching reading, in using the developed materials, the teachers should create a good atmosphere in the classroom, play the roles that their students expect, and encourage them to read.

3. For the other researchers

For those who want to develop other learning materials, it is suggested that they have to pay attention to the learners' needs. Then, in designing learning materials, researchers need to be creative.

\section{REFERENCES}

Graves, Kathleen. (2000). Designing language courses: A guide for teachers. Boston: Heinle\&Henle Publishing.

Grellet, F. (1981). Developing Reading Skills. Cambridge: Cambridge University Press.

Hutchinson, T. and Waters, A. (1987). English for specific purposes. Cambridge: Cambridge University Press. York: Cambridge University Press.

Klinger, J.K, Vaughn, S., and Boardman, A (2007). Teaching Reading Comprehension to Students with Learning Differences. New York, NY: Gulford Press

Law, J. (2013). Writing Genre - A Structured Approach. Rigby 
McEntire, Jo. (2003). Read Ahead: Reading and Life Skills Development.

Longman pearson Education

Nesi, H., and Gardner, S. (Eds). (2012). Families of Genres of Assessed Writing. Cambridge: Cambridge University Press.

Richards, Jack. (2001). Curriculum development in language teaching. New York: Cambridge University Press.

Risangkusmo, Wulur. (2015). Developing Reading Learning Materials For Year XI Students Of Computer Engineering And Networking Department At SMAK 1 Serayu. Unpublished Thesis. Yogyakarta: Universits Negeri Yogyakarta. 